\title{
Management of Special Education: Study of Effectivenes on Inclusion Education Service
}

\author{
Asep Sunandar \\ State University of Malang, Indonesia \\ asep.sunandar.fip@um.ac.id
}

\author{
Ade Dian Firdiana \\ State University of Surabaya, Indonesia \\ adedianfirdiana@gmail.com
}

\begin{abstract}
Special education is an education service program intended for students who have the limitation to follow the process of education both physically and mentally, and or learners who have the potential of intelligence and special talent. The Indonesian people generally have a view to separating the educational process among normal children of children with special needs. This view has resulted in the dichotomy and even the limitations of social space for children with special needs in actualizing their abilities. This study explains how the inclusion education process is implementing in schools, as an educational service that provides equal opportunities for children with special needs to socialize and learn together. The review process was conducted on various literature and previous research results. It was found that the inclusion education process is a guarantee of human rights to obtain equal education services for all learners. The process of inclusive education requires understanding and care of the citizens of the school so that children with special needs can develop in line with age and psychological development.
\end{abstract}

Keywords: management, special education, inclusion

\section{INTRODUCTION}

Education is a human right, everyone is entitled to education services ranging from basic education to higher education. Awareness of the importance of education is expressed in various agreements both national and international. In an international context the agreement was reached in the world education forum that resulted in a Dakar agreement of 2000, known as the education for all accord. The United Nations (UN) ratified Dakar agreement with the Millennium Development Goals (MDGs) there are eight state agreements in the world to tackle poverty and hunger, achieve basic education for all, promote gender equality and empower women, reduce child mortality, improve maternal health, Fighting HIV / AIDS, malaria and other infectious diseases, ensuring environmental sustainability, developing a global partnership for development. In 2015, the agreement on MDGs is followed by the agreement called SDGs (Sustainable Development Goals). There are three main points: poverty handling, justice and equality, and the handling of global climate change. Education is believed to be the key to achieving the MDGs and SDGs targets (UNESCO, 2014).

Nationally the recognition of education as a human right is contained in the 1945 Constitution of the Republic of Indonesia article 31 paragraph 1 "Every citizen is entitled to education" (Government of Indonesia, 2002). National Education System Act No. 20 of 2003 Article 4 (1) education is conducted in a democratic and fair and non-discriminatory manner by upholding human rights, religious values, cultural values and national pluralism. The decree affirms that Indonesia recognizes education as a human and governmental right to guarantee the fulfillment of such human rights (Government of the Republic of Indonesia, 2012).

The above national and international agreements affirm that all Indonesian citizens and the world without exception are entitled to education services. Children with Special Needs (ABK) as one part of the citizens of the world certainly have the same right to get educational services. But in practice there is still discrimination and unfavorable treatment of them. In the context of education, it is known as inclusive education model, which is a formal education service that serves all students in both physical and mental condition as well as the students of ABK. Inclusive education services are intended to integrate the educational process so that equality among children with special needs and normal children is possible.

Inclusive education can be defined as specially designed teaching and assistance for children of special needs in the context of regular education environments (Suparno, 2010). Inclusion education as a process to increase participation and reduce exceptions with an effective way of responding to the needs of different learners (Jasbir Kaur \& Babita Arora, 2014). Inclusion education is an effort by the government to provide equality to children with special needs to be able to socialize and enjoy the same educational services, as accepted by normal learners. People in general still see children with special needs as an obstacle or even an obstacle in implementing learning effectively. Given their limitations can lead to the process of education becomes slow. These views are certainly very discriminatory and show low concern for fellow human beings. Through inclusive education program is expected awareness and public awareness of the needs of $\mathrm{ABK}$ increasingly high. The inclusion education process is not intended for $\mathrm{ABK}$ to have the same achievement as normal children, but aimed at ABK having the opportunity to obtain quality education services, opportunities to socialize with fellow children, the growth of empathy and sympathy from normal children to the crew and the caring and mutual care understanding among the citizens of the school with the crew.

To realize the process of inclusion education is good, would require an effort to improve the management system of inclusive education services. The inclusion education process that took place in Indonesia was limited to having special needs children, there were teachers for the crew and the learning 
process that runs in general. Some of these things are considered not in line with the education process required by $\mathrm{ABK}$. The management of inclusive education services is a process that regulates the inclusion education system from new admissions, curriculum formulation, instructional design, modeling of evaluation and development of school culture in line with the spirit of educational equality for all learners, both normal students and students with special needs. The presentation of this article will present an egalitarian inclusion educational model of management based on the results of various literature studies from different countries.

\section{METHODS}

The process of article writing is done by reference study method, the author reads, finds meaning and draws conclusions based on secondary data obtained. Secondary data collection is conducted by taking into account various references to both international journal articles and national journals. The process of deduction is deductive from the general truth to a more specific truth.

\section{REFERENCES STUDY \\ Philosophy of Inclusive Education}

The concept of inclusive education services can not be separated from the ideology of democracy. The recognition of the rights of citizens and the equality of citizens of the law before the law is a renewal of the previous system which states that power is centralized in the ruling elite or known oligarchy. In education system known as democracy education and democratic education. Democratic education can be interpreted as a process of conveying knowledge about democracy, while democratic education emphasizes the absorption of democratic values as part of behavior both functionally and practically (Yolcu, 2015).

Education is a vehicle in planting the seeds of democratic views, in addition to education is also a machine in developing the science of democracy itself. Democracy is a view and science that tends to develop dynamically, the implementation of democratic views is not only limited to the government diarea, but extends to all the joints of life. Education has two roles in the framework of the development of democracy, namely as an object that accepts democracy as well as a subject that develops the science of democracy. (Willinsky, 2002) develops an experiment on democracy and educational culture, a democratic culture can be developed from class and school to forming a global society.

The development of the concept of democracy requires a conspicuous effort, considering that democracy is a system that regulates the human life in the framework of social interaction. (Evkuran, 2013) states that democratic education requires a process of konprehenship, given that in the process required the support of material, intelligence and community participation. The integration between education and democracy produces a new society order that can be used as a guide in social life.
Education for children with special needs through an inclusive education service system is an elaboration of democratic views. Inclusive education expects equality and equal services for all children, both physically and mentally disabled as well as normal children. Democracy is a foothold in the process of inclusive education to achieve high awareness and tolerance among the academic community of the school.

\section{Special Education Services in Europe}

European countries are known as the region of countries that have high advances in the field of education. The continent of Europe is often the center of learning of other countries in developing education and science. The author tries to explore the inclusive education process that occurred in the countries of New Zealand, Italy, Turky and Hungary. This reference study is expected to give an idea of how the inclusion education process should be done. Observing the various policies that have been implemented in these countries is expected we can get a valuable lesson, so it can be formulated recommendations in order to improve the system of inclusive education services in Indonesia.

New Zealand is a country that experienced rapid development of education. Education is the main service of government, financing and the fulfillment of educational needs undertaken by the government. The educational process starts from the level of early childhood education that is age 0 to 5 years, primary education 1 samapai with 8 years, secondary school 913 years and tertiary education above 16 years. Especially for children with special needs free education service can dinikamti until 21-year-old child (Powell EdD, 2012).

The New Zealand Government defines special education as an extra service, adopting environmental programs or learning, equipment and special materials to support children and youth in accessing established curricula. The Government guarantees that every citizen including those with special needs will receive the same educational service. The educational process for children with special needs in basic education is conducted as individual learning that helps find the needs of learners, the learning barrier is overcome by developing good relationships between schools and parents.

Special education services in Turkey are implemented with reference to the provision that special education is undertaken by providing methods and techniques that directly prepare educational plans that are appropriate to the needs of children. The process of education is done by treating the same among children with special needs and normal according to age range among them. Meanwhile, education for children with special needs in Italy is done by giving the same opportunities as normal children receive. Special education is done with the aim to assist the child in developing character. The education process is collaborative among teachers, parents and government (Demirok, 2015). 


\section{Management of Inclusion Education}

The success of the inclusive education program can not be separated from the managerial efforts. The wide range of inclusive education requires handling and applying the correct management rules. Management is a science-oriented process of managing various organizational resources through the stages of planning, implementation, organizing and evaluation in order to achieve organizational goals effectively and efficiently.

In implementing proper and appropriate inclusive education, there needs to be a good managerial system where all aspects of support are mutually sustainable. Ideal inclusion education is in terms of acceptance of students that is by accepting students ABK (child with special need) not accompanied by cognitive barriers, acceptance of students must go through the stages of assessment by psychologists, pediatricians, doctors grow flowers if not there then formed an assessment team from the school, the model modified curriculum for children of crew, special escort teachers either from extraordinary educational backgrounds or psychology graduates or other educational backgrounds but already trained, special classrooms for children of crew if experiencing things that need to be separated from the classroom regular. And socialization for all citizens of the school both students, teachers, administration, and of course parents guardian.

Budiyanto (2012) Describes the implementation of inclusive education can be done by dividing the three class models, regular classes are used for students who experience impairment at the intermediate level and have a higher potential cognitive ability. The source class is used for students who experience a decrease in value in the medium, and a special classroom is used for students who experience moderate impairment and fall into the severe category.

Class division is intended for the process of handling and providing services to students with special needs done in accordance with the potential of students. The distribution of students in inclusive education services should take into account the potential and level of learning disabilities of students with special needs. If students fall into the category of low cognitive abilities then not necessarily included in the regular class. The process should be done gradually so that no one harms both normal students and students with special needs.

\section{CONCLUSION}

Inclusive education services are an effort to provide justice and equal rights for all citizens. The basic philosophy of inclusive education services is the view of democracy, in which all citizens have the same rights and obligations, so that there is no dichotomy among fellow citizens. The inclusion education process that takes place in different countries with its own policies, provides experience and examples for the Indonesian government. Taking into account the educational processes occurring in European countries, especially in the implementation of special education it is seen that they provide equal education services by keeping in mind the potential level of children with special needs that can be developed. The process of inclusive education requires understanding and care of the citizens of the school so that children with special needs can develop in line with age and psychological development. Management of inclusive education services can be done by dividing the class of services according to the condition of the students. Class divisions can be made into three models: regular classes, source classes and special classes. Each class is reserved for children with special needs in line with the potential of the child.

\section{REFERENCES}

[1] Budiyanto. 2012. Best Practices of Inclusive Education in Japan, Australia, India and Thailand: How to be Implemented in Indonesia. ICER 2012: Challenging Education for Future Change. September 8-9, 2012, KKU, Thailand.

[2] Demirok, M. S., and Meltem, H. 2015. The Comparison of Early Childhood Special Education System in Turkey with in Hungary, Italy and Romania. Procedia - Social and Behavioral Sciences, 205, 648 654.

[3] Evkuran, M. 2013. Essentials of the Education on Democracy. Procedia - Social and Behavioral Sciences, $\quad 106, \quad 1103-1112$. https://doi.org/10.1016/j.sbspro.2013.12.124

[4] Jasbir, K., \& Babita, A. 2014. Inclusive Education - an Integrated Approach. IMPACT: International Journal of Research in Humanities, Arts and Literature, 2(2), 59-64. Retrieved December 2, 2016, from http://www.impactjournals.us/journals.php?id=11\&jtyp $\mathrm{e}=2$ \&page $=4$.

[5] Pemerintah Republik Indonesia. 2002. Undang-Undang Dasar 1945. Jakarta: Republic of Indonesia.

[6] Pemerintah Republik Indonesia. 2012. Undang-Undang Republik Indonesia Nomor 20 Tahun 2003 tentang Sistem Pendidikan Nasional. Jakarta: Republic of Indonesia.

[7] Powell EdD, D. 2012. Electronic Journal for Inclusive Education A Review of Inclusive Education in New Zealand. Electronic Journal for Inclusive Education, 2(210). Retrieved July, 21, 2016, from http://corescholar.libraries.wright.edu/ejie.

[8] Suparno. 2010. Pendidikan Inklusif Untuk Anak Usia Dini. Jurnal Pendidikan Khusus, 7(2), 1-8.

[9] UNESCO. 2014. Sustainable Development - Post-2015 Begins with Education. New York: UNESCO.

[10] Willinsky, J. 2002. Democracy and Education: The Missing Link May be Ours. Harvard Educational Review, 72(3), 367-392. Retrieved June, 2, 2016, from http://pkp.sfu.ca/files/Democracy.pdf.

[11] Yolcu, E. 2015. Analyzing the Awareness of PreService Teachers' Towards Democracy Inclusion in Education. Procedia - Social and Behavioral Sciences, 197, 18661873. https://doi.org/10.1016/j.sbspro.2015. 07.248 . 